\title{
ARTICLE
}

\section{A case of tetrophthalmia with unilateral synophthalmia in an unborn fetus of blue shark Prionace glauca (Carcharhiniformes, Carcharhinidae)}

Un caso de tetroftalmia con sinoftalmia unilateral en un feto nonato de tiburón azul Prionace glauca (Carcharhiniformes, Carcharhinidae)

\section{Víctor Pastén-Marambio ${ }^{1}$, Valentina Hevia-Hormazábal ${ }^{1}$, Enzo Acuña ${ }^{1,2^{*}}$ and J.M. Alonso Vega ${ }^{1}$}

\author{
${ }^{1}$ Departamento de Biología Marina, Facultad de Ciencias del Mar, Universidad Católica del Norte, Casilla 117, Coquimbo, Chile. \\ *eacuna@ucn.cl \\ ${ }^{2}$ Millenium Nucleus for Ecology and Sustainable Management of Oceanic Islands (ESMOI), Departamento de Biología Marina, \\ Universidad Católica del Norte, Coquimbo, Chile
}

\begin{abstract}
Resumen.- Este estudio describe y clasifica un caso de malformaciones múltiples en un feto nonato de tiburón azul Prionace glauca, extraído de una hembra grávida capturada durante una campaña de investigación biológica de tiburones en el norte y centro de Chile. El espécimen analizado presenta tetroftalmia con sinoftalmia unilateral, anomalía caracterizada por la existencia de 4 globos oculares, dos de los cuales están parcialmente fusionados. Además, el esqueleto axial del feto muestra lordosis torácica y torsión helicoidal en la porción abdómino-caudal. Este es el primer registro mundial de tetroftalmia con sinoftalmia unilateral en condrictios.
\end{abstract}

Palabras clave: Chondrichthyes, malformaciones orbitales, siameses, captura incidental, embriogénesis

Abstract.- This study describes and classifies a case of multiple malformations in an unborn blue shark Prionace glauca fetus, which was extracted from a gravid female captured during a research campaign addressed to the biological study of sharks in northern and central Chile. The analyzed specimen shows tetrophthalmia with unilateral synophthalmia, anomaly characterized by the existence of 4 ocular globes, two of which are partially fused. In addition, the axial skeleton of the fetus shows thoracic lordosis and helical torsion in the abdominal-caudal portion. This is the first world report of tetrophthalmia with unilateral synophthalmia in chondrichthyans.

Key words: Chondrichthyes, orbital malformations, conjoined twins, bycatch, embryogenesis

\section{INTRODUCTION}

Although its occurrence is rare (Black et al. 2012), the presence of morphological abnormalities has been widely reported in humans (e.g., Howard 1977, Hausmann et al. 1992, Jensen et al. 2007) and animals (e.g., Maggs et al. 2009). In the latter, such malformations have even been experimentally induced, by genetic manipulation (Halder et al. 1995) as well as by the action of physical and chemical agents (Raven et al. 1955, Howard 1977), suggesting a multifactorial etiology. Examples of this can also be found in nature, where different orbital alterations have been associated to causes so diverse as chromosomal anomalies (Howard 1977), phytotoxic conditions, hypovitaminosis (Maggs et al. 2009) and intrauterine infections (Sadler \& Langman 2007).

Relatively few reports of morphological abnormalities in sharks are found in the literature, which have mainly focused in the description of bicephalous (Goto et al. 1981, Bejarano-Álvarez et al. 2011, Delpiani et al. 2011, Galván-Magaña et al. 2011, Ehemann et al. 2016), diprosopus (Hevia-Hormazábal et al. 2011) and xyphopagus twins (Ferreira et al. 2000) ${ }^{1}$. Other

${ }^{1}$ Ferreira LA, TGA Ferreira \& LE Oliveira. 2000. Ocorrência de xifopagia em embrião de tubarão-azul, Prionace glauca (Linnaeus, 1758) (Carcharhinidae, Carcharhiniformes). In: Resumos da 2a Reunião da Sociedade Brasileira para Estudo em Elasmobrânquios - SBEEL, p. 71 
deformities include spinal cord (Mancini et al. 2006) and dental abnormalities (Sáez \& Pequeño 2010). Albinism has also been reported in several species (e.g., Texeira \& Araujo 2002).

Other morphological anomalies reported in sharks include cyclopia (Mancini et al. 2006, Castro 2011) and bilateral absence of eyes (Bejarano-Álvarez et al. 2011), called anophthalmia (Sadler \& Langman 2007). These two are part of a wide array of orbital anomalies, which also comprises synophthalmia (incomplete ocular fusion), microphthalmia (presence of severely hypoplastic eyes), diplophthalmia (total duplication of one eye) (Hausmann et al. 1992, Sadler \& Langman 2007) and development of supernumerary eyes (Raven et al. 1955, Jensen et al. 2007).

Prionace glauca (Linnaeus, 1758) is a neritic-oceanic species, circumglobal in tropical and temperate seas (Compagno 1984), and its distribution in Chile extends from Arica $\left(18^{\circ} \mathrm{S}\right)$ to Puerto Montt $\left(41^{\circ} \mathrm{S}\right)$. Its reproduction is placental viviparous (Galván-Magaña et al. 2011), with a gestational period of 9 to 12 months (Nakano \& Seki 2003), after which the female gives birth to 4 to 135 offsprings per liter (Compagno 1984). The size at birth is between 35 and 44 cm total length (LT) (Sáez \& Pequeño 2010), with newborn specimens showing advanced developmental stage and total independence on the mother (Compagno 1984).

Recently, several embryonic abnormalities have been reported in Prionace glauca (Bejarano-Álvarez et al. 2011, Galván-Magaña et al. 2011, Hevia-Hormazábal et al. 2011, Ehemann et al. 2016) and other carcharhinid species (Delpiani et al. 2011). In the present study, a case of tetrophthalmia with unilateral synophthalmia in a $P$. glauca fetus captured in Chilean waters is described and classified.

\section{MATERIALS AND METHODS}

Between November 2000 and August 2001, during a biological study on pelagic sharks off northern and central Chile, 33 gravid female $P$. glauca were captured and examined in the laboratory (Acuña et al. 2001). Inside one of them, a fetus with multiple morphological abnormalities was found, fixed with 10\% formaldehyde and stored in $90 \%$ ethanol in the ichthyological collection of the Guayacán Campus of Universidad Católica del Norte, Chile (Reference code SCBUCN - 3617). For the descriptive analysis of the specimen, external morphological, morphometric (Compagno 1984) and radiological examinations were done. The craniofacial deformities were classified according to the criteria described by Hausmann et al. (1992).

\section{Results}

The analyzed specimen is a female unborn fetus of 152 $\mathrm{mm}$ TL. Its other morphometric data is included in Table 1. Morphologically, the specimen shows 4 eyeballs: 3 laterals (Figs. 1a y b) and one submedial, localized between the middle line and the left ocular region (Fig. 1c). The right (Fig. 1b) and submedial eyeballs are simple, while the left ones are partially fused (Fig. 1a). These last ones, longitudinally joined at the iris level, are the same size (Table 1) and share a common sclera. The submedial eye, partially covered by dermic folds, is hypoplastic (Fig. 1c). Externally, the Meckel cartilage looks normal, while the palatoquadrate shows a notorious deformity (Fig. 1). Teeth, present in both mandibles, do not show morphological anomalies. The rostrum is shifted towards the left in the sagittal plane and shows a slight clockwise torsion (Fig. 1c). The spiracles are absent, but the number and relative position of fins and gill slits are normal (Table 1, Fig. 1). The pectoral and pelvic fins are slightly asymmetric (Table 1, Fig. 1), the dorsal fins are folded (Fig. 1a), and the caudal, coiled (Fig. 1). The umbilical cord is $14.8 \mathrm{~mm}$ long and $8.0 \mathrm{~mm}$ wide (Fig. 1c). The axial skeleton shows thoracic lordosis and dextrogyre helical torsion in the abdominal-caudal portion (Fig. 1). The epidermal pigmentation is normal, except for a darker sector that connects the three periocular regions (Fig. 1c).

\section{Discussion}

Based on the classification criteria used, we propose the term tetrophthalmia with unilateral synophthalmia to denote the orbital malformation reported in this study. Due to the invariable association between synophthalmia and severe alterations in brain development, the described dysmorphic assemblage is incompatible with postnatal life (Hausmann et al. 1992, Sadler \& Langman 2007).

This is the first world record of tetrophthalmia with unilateral synophthalmia in chondrichthyans, and there have been no reports of this disorder in nonchondrichthyan vertebrates. According to Hausmann et al. (1992), this malformation would be 
Table 1. Morphometric characterization ( $\mathrm{mm}$ ) of the tetrophthalmic blue shark fetus caught in Chilean waters / Caracterización morfométrica (mm) del feto de tiburón azul tetroftálmico capturado en aguas chilenas

\begin{tabular}{|c|c|c|c|c|c|c|c|c|c|}
\hline Morphometric characteristics & Size & Right & $\begin{array}{l}\text { Sub- } \\
\text { medial }\end{array}$ & Left & Morphometric characteristics & Size & Right & $\begin{array}{c}\text { Sub- } \\
\text { medial }\end{array}$ & Left \\
\hline Total length & 152.0 & & & & Pelvic-fin length & & 20.2 & & 17.2 \\
\hline Precaudal length & 144.4 & & & & Pelvic-fin base & & 12.3 & & 9.4 \\
\hline Predorsal length & 113.4 & & & & Pelvic-fin height & & 11.3 & & 7.1 \\
\hline Cephalic length & 86.9 & & & & Pelvic-fin anterior margin & & 19.1 & & 15.8 \\
\hline Cephalic height & 31.8 & & & & Pelvic-fin posterior margin & & 14.3 & & 8.2 \\
\hline Cephalic width & 44.2 & & & & First dorsal-fin length & 33.2 & & & \\
\hline Prebranchial length & & 75.6 & & 78.0 & First dorsal-fin base & 25.4 & & & \\
\hline Preorbital length & & 34.2 & 36.6 & 36.9 & First dorsal-fin height & 17.7 & & & \\
\hline Prenarial length & & 22.2 & & 24.8 & First dorsal-fin anterior margin & 30.1 & & & \\
\hline Preoral length & 50.3 & & & & First dorsal-fin posterior & 25.4 & & & \\
\hline & & 85.5 & & 86.8 & $\begin{array}{l}\text { margin } \\
\text { Second dorsal-fin length }\end{array}$ & 22.3 & & & \\
\hline Preumbilical length & 77.8 & & & & Second dorsal-fin base & 17.5 & & & \\
\hline Prepelvic length & & 107.8 & & 117.0 & Second dorsal-fin height & 6.9 & & & \\
\hline $\begin{array}{l}\text { Preanal length } \\
\text { Eye length }\end{array}$ & 112.2 & 19.5 & 12.9 & 11.1 & $\begin{array}{l}\text { Second dorsal-fin anterior } \\
\text { margin }\end{array}$ & 14.4 & & & \\
\hline Eye height & & 11.4 & 9.2 & 14.4 & $\begin{array}{l}\text { Second dorsal-fin posterior } \\
\text { margin }\end{array}$ & 16.8 & & & \\
\hline Mouth length & 12.8 & & & & $\begin{array}{l}\text { margin } \\
\text { Anal-fin length }\end{array}$ & 21.3 & & & \\
\hline Mouth width & 26.2 & & & & Anal-fin base & 11.2 & & & \\
\hline Nostril width & & 5.3 & & 5.4 & Anal-fin height & 7.7 & & & \\
\hline Interorbital space & & 9.4 & & 12.0 & Anal-fin anterior margin & 14.4 & & & \\
\hline Internarial space & 10.1 & & & & Anal-fin posterior margin & 9.4 & & & \\
\hline Intergill length & & 10.0 & & 14.6 & Trunk height & 41.1 & & & \\
\hline First gill slit height & & 12.7 & & 11.1 & Trunk width & 38.0 & & & \\
\hline First gill slit height & & 13.4 & & 8.6 & Umbilical cord length & 14.8 & & & \\
\hline Third gill slit height & & 13.6 & & 9.7 & Umbilical cord maximum & 8.0 & & & \\
\hline Fourth gill slit height & & 13.3 & & 10.3 & (subdistal) width & & & & \\
\hline Fifth gill slit height & & 11.4 & & 9.0 & & & & & \\
\hline
\end{tabular}

consecutive to twin fusion, being in the same pathological context of bicephalic and diprosopic twins (Fig. 2).

The optic primordia are formed from the neural plate, after the division of the ocular field (Li et al. 1997). This process, similar in all vertebrates (Cagan \& Reh 2010), is regulated by a polygenic system, which correct performance is key for the existence of bilateral eyes (Varga et al. 1999, Sadler \& Langman 2007). From this perspective, the presence of 4 eyes in the analyzed specimen is attributable to the preexistence of two ocular fields, one of which (the one from the left twin) did not separated, causing unilateral synophthalmia.

Malformations in sharks have been attributed to several causes, among them genetic anomalies, parasitosis, malnutrition, arthritis, mechanical injuries, presence of tumors and pollution (Mancini et al. 2006, Delpiani et al. 2011). However, these causes should not be considered for $P$. glauca because of the highly migratory lifestyle of this species (Acuña et al. 2001). Another cause, of special importance in P. glauca, could be polyembriony (Mancini et al. 2006), since this species produce large litters, up to 135 offsprings, being the most fecund species of the group (Compagno 1984). Thus, the intrauterine area of $P$. glauca could be small to bear a high number of offsprings, with the consequent risk of placental insufficiency. Due to this 


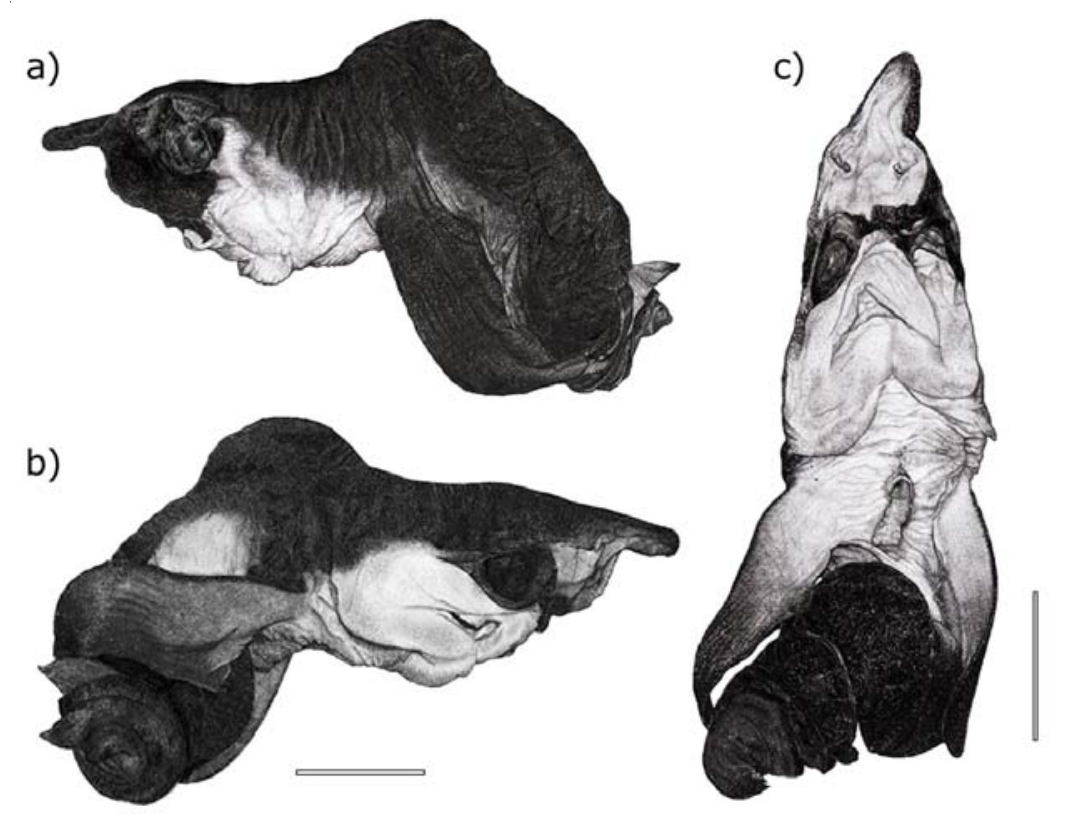

Figure 1. Blue shark fetus affected by tetrophthalmia with unilateral synophthalmia caught in Chilean waters. a) Left lateral view, b) right lateral view and c) ventral view. Scale bar: $\mathbf{3 0 ~ m m ~ / ~ F e t o ~ d e ~ t i b u r o ́ n ~ a z u l ~ a f e c t a d o ~ p o r ~ t e t r o f t a l m i a ~ c o n ~ s i n o f t a l m i a ~ u n i l a t e r a l ~ c a p t u r a d o ~ e n ~}$ aguas chilenas. Vista lateral derecha (a), lateral izquierda (b) y ventral (c). Barra escalar: $30 \mathrm{~mm}$

a)

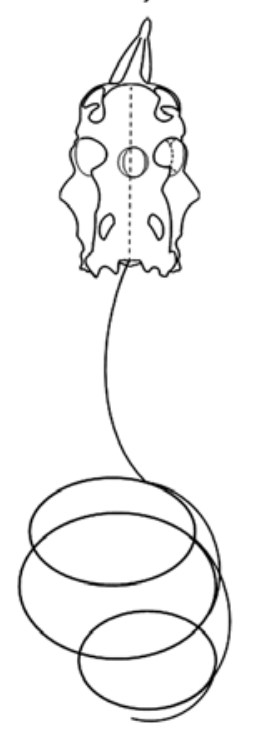

b)

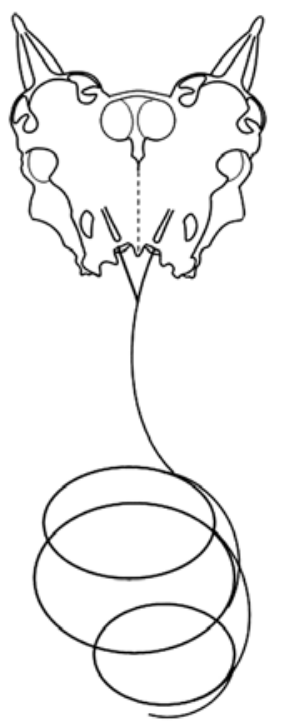

c)

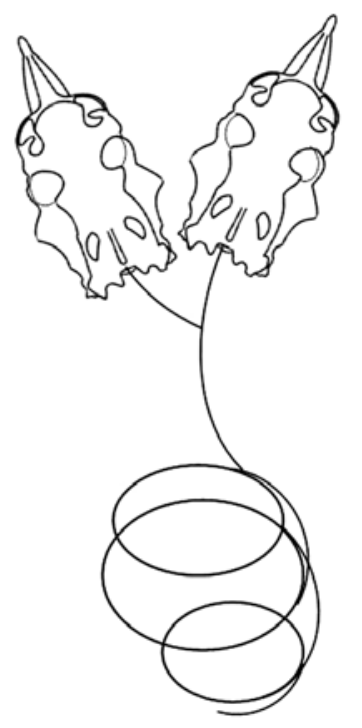

Figure 2. Comparative scheme of 3 blue shark specimens with congenital malformations: (a) tetrophthalmic fetus described in the present study; (b) diprosopus twins reported by Hevia-Hormazábal et al. (2011); (c) bicephalous twins presented by Goto et al. (1981) / Esquema comparativo de 3 especímenes de tiburón azul con malformaciones congénitas: (a) feto tetroftálmico descrito en el presente estudio; (b) gemelos diprósopos reportados por Hevia-Hormazábal et al. (2011); (c) gemelos bicéfalos presentados por Goto et al. (1981) 
fact, nutrient transfer to the fetus could be limited, producing deleterious effects over their development and growth, which is evident if abnormal fetuses are compared with normal ones of similar age (e.g., HeviaHormazábal et al. 2011).

Orbital malformations have generally low prevalence in vertebrates (Black et al. 2012), being particularly rare in chondrichthyan fish, where only two cases of cyclopia (Mancini et al. 2006, Castro 2011, Bejarano-Álvarez \& Galván-Magaña 2013) and one of anophthalmia (Bejarano-Álvarez et al. 2011) have been reported, all of which correspond to $P$. glauca.

Given this lack of records, the analysis of commercially captured sharks could constitute an effective alternative to improve the knowledge of the etiology and epidemiology of these deformities. However, initiatives such as this could be faced with different logistical difficulties. This partially occurs in the chondrichthyan fisheries in Chile, where P. glauca is not a target species, but is mainly part of the bycatch of the artisanal and industrial fleets that target other species, such as Isurus oxyrinchus and Xiphias gladius, respectively (Acuña et al. 2001). The artisanal longline fishery that targets $I$. oxyrinchus operates primarily seasonally (spring-summer) in the coastal zone off northern Chile and normally does not have access to adult specimens. By contrast, in the industrial longline fishery that targets $X$. gladius, most of the $P$. glauca specimens used to be discarded, and only their fins are retained, making it difficult to have access to samples of this species (Acuña et al. 2002). However, in this last case, Chile passed during 2011 a law against finning, and now the whole bodies of the sharks caught must be landed, making it possible to have access to $P$. glauca female specimens.

\section{ACKNOWLedgments}

We are grateful to D. Céspedes, N. Piaget and G. Díaz for valuable advice and collaboration during the process of this study. This contribution was supported by Department of Marine Biology of Universidad Católica del Norte and Fondo de Investigación Pesquera (FIP) - Project $\mathrm{N}^{\circ} 2000-23$. JMA Vega acknowledges the support of BECA CONICYT and Programa de Doctorado en Biología y Ecología Aplicada (<www.bea.cl $>$ ).

\section{LITERATURE CITED}

Acuña E, L Cid, E Pérez, I Kong, M Araya, J Lamilla \& J Peñailillo. 2001. Estudio biológico de tiburones (marrajo dentudo, azulejo y tiburón sardinero) en la zona norte y central de Chile. Informes Técnicos FIP, FIP/IT N ${ }^{\circ} 2000-$ 23: 1-112. <http://www.subpesca.cl/fipa/613/articles88952_informe_final.pdf>

Acuña E, JC Villarroel \& R Grau. 2002. Fauna íctica asociada a la pesquería de pez espada (Xiphias gladius Linnaeus). Gayana 66: 263-267.

Bejarano-Álvarez OM \& F Galván-Magaña. 2013. First report of an embryonic dusky shark (Carcharhinus obscurus) with cyclopia and other abnormalities. Marine Biodiversity Records 6(11): 1755-2672.

Bejarano-Álvarez OM, F Galván-Magaña \& RI OchoaBáez. 2011. Further observations on foetal abnormalities in the blue shark Prionace glauca (Chondrichthyes: Carcharhinidae) from north-west Mexico. Marine Biodiversity Records 4: e82. <https://doi.org/10.1017/ S1755267211000790>

Black EH, FA Nesi, CJ Calvano, GJ Gladstone \& MR Levine. 2012. Smith and Nesi's ophthalmic plastic and reconstructive surgery, 1330 pp. Springer-Verlag, New York.

Cagan RL \& TA Reh. 2010. Invertebrate and vertebrate eye development, 312 pp. Elsevier, San Diego.

Castro JI. 2011. The sharks of North America, 612 pp. Oxford University Press, New York.

Compagno LJV. 1984. FAO Species Catalogue. Vol.4. Sharks of the world, an annotated and illustrated catalogue of shark species known to date. Part 2. Carcharhiniformes. FAO Fisheries Synopsis 125 4(2): 251-655.

Delpiani SM, MY Deli Antoni, SA Barbini \& DE Figueroa. 2011. First record of a dicephalic specimen of tope Galeorhinus galeus (Elasmobranchii: Triakidae). Journal of Fish Biology 78(3): 941-944.

Ehemann N, J Marín-Sanz \& M Barany-González. 2016. Two cases of two-head shark embryos, smalleye smoothhound Mustelus higmani and blue shark Prionace glauca. Boletín de Investigaciones Marinas y Costeras 45(1): 149153.

Galván-Magaña F, O Escobar-Sánchez \& M CarreraFernández. 2011. Embryonic bicephaly in the blue shark, Prionace glauca, from the Mexican Pacific Ocean. Marine Biodiversity Records 4: e1. <doi:https://doi.org/10.1017/ S1755267210001120>.

Goto M, T Taninuchi, N Kuga \& M Iwata. 1981. Four dicephalous specimens of blue shark, Prionace glauca, from Japan. Japanese Journal of Ichthyology 28(2): 157165.

Halder G, P Callaerts \& WJ Gehring. 1995. Induction of ectopic eyes by targeted expression of the eyeless gene in Drosophila. Science 267: 1788-1792. 
Hausmann N, FH Stefani \& EO Lund. 1992. Diplophthalmia versus cyclopia and synophthalmia. Mechanisms of doubling of the eye. Documenta Ophthalmologica 79(3): 201-219.

Hevia-Hormazábal V, V Pastén-Marambio \& A Vega. 2011. Registro de un monstruo diprósopo de Tiburón azul (Prionace glauca) en Chile. International Journal of Morphology 29(2): 509-513.

Howard RO. 1977. Chromosomal abnormalities associated with cyclopia and synophthalmia. Transactions of the American Ophthalmological Society 75: 505-538.

Jensen H, SA Pedersen, OA Jensen, M Herning \& M Warburg. 2007. Unilateral ocular duplication. Ophthalmic Genetics 28(2): 83-88.

Li H, C Tierney, L Wen, JY Wu \& Y Rao. 1997. A single morphogenetic field gives rise to two retina primordial under the influence of the prechordal plate. Development 124(3): 603-615.

Maggs DJ, PE Miller \& R Ofri. 2009. Fundamentos de oftalmología veterinaria, 504 pp. Elsevier, Madrid.

Mancini PL, AL Casas \& AF Amorim. 2006. Morphological abnormalities in a blue shark Prionace glauca (Chondrichthyes: Carcharhinidae) foetus from southern Brazil. Brazilian Archives of Biology and Technology 69(6): 1881-1884.
Nakano H \& M Seki. 2003. Synopsis of biological data on the blue shark, Prionace glauca Linnaeus. Bulletin of the Fisheries Research Agency 6: 18-55.

Raven P, AC De Room \& AM Stadhouders. 1955. Morphogenetic effects of a heat shock on the eggs of Limnaea stagnalis. Journal of Embryology and Experimental Morphology 3(2): 142-159.

Sadler TW \& J Langman. 2007. Embriología médica con orientación clínica, 386 pp. Editorial Médica Panamericana, Buenos Aires.

Sáez S \& G Pequeño. 2010. Claves para el reconocimiento taxonómico dentario en taxa del Superorden Squalomorphi de Chile (Chondrichthyes: Elasmobranchii). Latin American Journal of Aquatic Research 38(2): 474-484.

Texeira SF \& MG Araujo. 2002. First record of albinism in the smooth dogfish Mustelus schimitti from Southern Brazil. Brazilian Archives of Biology and Technology 45(2): 241243.

Varga ZM, J Wegner \& M Westerfield. 1999. Anterior movement of ventral diencephalic precursors separates the primordial eye field in the neural plate and requires cyclops. Development 126(24): 5533-5546. 